\title{
ANALISIS FAKTOR KESULITAN BELAJAR DITINJAU DARI HASIL BELAJAR MATEMATIKA SISWA KELAS V SEKOLAH DASAR
}

\author{
Frita Devi Asriyanti* \\ Indah Sri Purwati \\ Pendidikan Guru Sekolah Dasar, STKIP PGRI Tulungagung \\ JL. Mayor Sujadi Timur No 7, Tulungagung, Jawa Timur, Indonesia \\ *email: frita@ stkippgritulungagung.ac.id
}

Artikel diterima: 27 Agustus 2018; disetujui: 31 Mei 2020

\begin{abstract}
The purpose of this study is to describe the faktors of learning difficulties in mathematics and analyze the faktors of learning difficulties in terms of the results of learning mathematics in fifthh grade elementary school students. This research uses a qualitative descriptive. Data collection techniques used a questionnaire instrument, observation guidelines, interviews, and documentation conducted during mathematics learning activities in Pagersari I Elementary School Tulungagung Regency. Data analysis techniques using triangulation techniques and observer perseverance. The data obtained are 55.93\% internal learning difficulties and 59.2\% external learning difficulties. Data analysis of learning outcomes obtained $36 \%$ of students have difficulty learning mathematics in the cognitive realm.
\end{abstract}

Keywords: Factors of learning difficulties; learning outcomes; mathematics; elementary school.

\begin{abstract}
Abstrak: Tujuan dari penelitian ini adalah untuk mendeskripiskan faktor kesulitan belajar pada mata pelajaran matematika dan menganalisis faktor kesulitan belajar ditinjau dari hasil belajar matematika siswa kelas V sekolah dasar. Penelitian ini menggunakan pendekatan kualitatif jenis kualitatif deskriptif. Teknik pengumpulan data menggunakan instrumen angket, pedoman observasi, wawancara, dan dokumentasi yang dilakukan pada saat kegiatan pembelajaran matematika di SDN Pagersari I Kabupaten Tulungagung. Teknik analisis data menggunakan teknik triangulasi dan ketekunan pengamat. Data yang diperoleh yaitu faktor kesulitan belajar intern 55,93\% dan faktor kesulitan belajar ekstern 59,2\%. Data analisis hasil belajar diperoleh $36 \%$ siswa mengalami kesulitan belajar matematika pada ranah kognitif.
\end{abstract}

Kata kunci: Faktor kesulitan belajar; hasil belajar; matematika; sekolah dasar.

Pendidikan adalah hidup (Mudyahardjo, 2010). Pendidikan adalah segala pengalaman belajar yang berlangsung dalam segala lingkungan dan sepanjang hidup. Pendidikan adalah suatu bagian kehidupan yang mempengaruhi pertumbuhan dan perkembangan individu. Pendidikan merupakan salah satu kebutuhan yang harus didapatkan oleh setiap manusia, karena tanpa pendidikan manusia tidak dapat belajar tentang ilmu pengetahuan dalam kehidupan. Pendidikan dapat diperoleh dari 
pendidikan formal dan pendidikan non formal. Pendidikan formal dapat diperoleh melalui sekolah, sedangkan pendidikan non formal dapat diperoleh dari lembaga lain, misalnya lembaga kursus. Sekolah dasar merupakan salah satu bagian dari pendidikan formal dan program wajib belajar di Indonesia. Pembelajaran di sekolah dasar bukan hanya berfokus pada ketuntasan belajar siswa tetapi juga pada penguatan karakter siswa (Judiani, 2010). Pada proses pembelajaran terjadi kegiatan belajar dan mengajar. Kegiatan belajar akan berlangsung secara maksimal jika potensi dan keterlibatan siswa dapat dioptimalkan selama proses pembelajaran.

Ahmadi dan Supriyono (2008) mengungkapkan bahwa perbedaan individu akan mempengaruhi tingkah laku belajarnya. Dalam situasi tertentu, siswa tidak dapat belajar sebagaimana mestinya karena mengalami kendala dalam belajar. Kendala yang dihadapi siswa selama belajar ini dapat disebut sebagai kesulitan belajar. Kesulitan belajar atau learning difficulty adalah suatu kondisi yang membuat siswa sulit untuk melakukan kegiatan belajar secara efektif (Jamaris, 2009). Seringkali usaha yang dilakukan untuk mencapai hasil belajar yang memuaskan tidak sebanding dengan hasil belajar yang didapatkan. Faktor yang mempengaruhi kesulitan belajar tidak mudah untuk ditetapkan karena faktor tersebut bersifat kompleks.

Hasil penelitian Novitasari \& Sihombing (2017) dan Waskitoningtyas (2016) menunjukkan bahwa terdapat dua faktor kesulitan belajar siswa, yang terdiri dari faktor internal dan faktor eksternal. Faktor internal/intern merupakan faktor dari dalam diri sendiri sementara faktor eksternal/ekstern merupakan faktor yang berasal dari luar diri siswa/lingkungan. Faktor intern dapat meliputi minat, motivasi, bakat serta hal-hal dalam diri siswa yang menghalangi siswa untuk dapat mengikuti pembelajaran secara efektif. Faktor ekstern meliputi kondisi lingkungan belajar, dukungan keluarga, metode atau media pembelajaran yang digunakan selama pembelajaran, dan semua hal yang terkait anak menjadi kesulitan belajar yang kemudian mempengaruhi hasil belajar siswa.

Kesulitan belajar juga sering ditemui dalam pembelajaran matematika sekolah dasar. Berdasarkan hasil wawancara dengan guru kelas V di SDN Pagersari I Kabupaten Tulungagung, diketahui bahwa siswa mengalami kesulitan belajar yang mengakibatkan rendahnya hasil belajar matematika di kelas tersebut. Salah satu faktor penyebab kesulitan belajar siswa adalah kurangnya perhatian orang tua karena mayoritas bekerja di luar negeri. Selain faktor tersebut guru meyakini bahwa terdapat faktor dari dalam diri siswa. Pada penelitian yang lain, Waskitoningtyas (2016) menganalisis kesulitan belajar siswa kelas V SD pada materi satuan waktu. Sementara itu, Triyono (2011) mengidentifikasi kesulitan belajar matematika di kelas rendah sekolah dasar di Kota Blitar. Penelitian ini akan berfokus pada analisis faktor kesulitan belajar siswa kelas $\mathrm{V}$ dalam pembelajaran matematika ditinjau dari hasil belajar siswa yang terdiri dari faktor intern dan 
ekstern. Materi yang dipilih disesuaikan dengan materi yang diajarkan di sekolah, yaitu pengolahan data.

\section{METODE}

Metode penelitian kualitatif sering disebut dengan metode penelitian naturalistik karena penelitiannya dilakukan pada kondisi yang alamiah (Sugiyono, 2014:14). Penelitian kualitatif adalah penelitian untuk memahami fenomena tentang apa yang dialami subjek penelitian yang dialami oleh subjek penelitian pada suatu konteks khusus yang alamiah dengan memanfaatkan berbagai metode ilmiah (Moleong, 2016:6). Penelitian ini menggunakan pendekatan kualitatif deskriptif.

Penelitian ini dimaksudkan untuk mengungkap secara mendalam tentang faktor kesulitan belajar ditinjau dari hasil belajar siswa peserta didik kelas V pada mata pelajaran matematika di SDN Pagersari I Kabupaten Tulungagung pada Tahun Pelajaran 2017/2018. Observasi dilakukan secara langsung pada peserta didik dan lokasi penelitian pada saat proses pembelajaran berlangsung. Faktor penyebab kesulitan belajar yang dialami siswa ditelusuri melalui pemberian angket dengan menggunakan indikator faktor intern dan faktor ekstern. Wawancara dilakukan kepada 3 sampel dengan sampel pertama siswa yang mendapat nilai paling rendah; sampel kedua siswa yang mendapat nilai sesuai dengan KKM; dan sampel ketiga adalah siswa yang mendapat nilai paling tinggi.

Teknik analisis pada angket faktor kesulitan belajar siswa menggunakan persentase dari skor yang diperoleh siswa dibandingkan dengan total skor maksimal. Hasil ini selanjutnya dikategorikan berdasarkan faktor kesulitan belajar dengan kriteria sangat rendah hingga sangat tinggi. Pembagian kategori tersebut dapat dilihat pada Tabel 1. Keabsahan data menggunakan teknik triangulasi dan ketekukan pengamatan pada saat penelitian.

Tabel 1. Kategori Faktor Kesulitan Belajar Berdasarkan Persentase

\begin{tabular}{ccc}
\hline No. & Persentase & Kriteria \\
\hline 1 & $75-100 \%$ & Sangat Tinggi \\
\hline 2 & $50-75 \%$ & Tinggi \\
\hline 3 & $25-50 \%$ & Rendah \\
\hline 4 & $1-25 \%$ & Sangat Rendah \\
\hline
\end{tabular}

(Diadaptasi dari Evita, dkk., 2015)

\section{HASIL DAN PEMBAHASAN}

Observasi dilakukan pada kegiatan belajar mengajar di kelas $\mathrm{V}$ pada mata pelajaran matematika. Pada kelas V, pembelajaran matematika pada kurikulum K13 tidak termasuk dalam pembelajaran tematik dan terpisah dari mata pelajaran yang lain. Kegiatan pembelajaran matematika diawali dengan ucapan salam dari Pak B, guru kelas V SDN Pagersari I. Selanjutnya Pak B memberikan nasehat, semangat, serta motivasi agar siswa memiliki sikap positif sebelum 
memulai pembelajaran. Pak B juga melakukan tanya jawab terkait kegiatan siswa di rumah serta membahas pekerjaan rumah yang telah diberikan pada pertemuan sebelumnya. Kegiatan pembelajaran matematika dilaksanakan pada materi pengolahan data.

Pak B meminta siswa untuk membentuk kelompok, sertiap kelompok terdiri dari 5 kelompok yang terdiri dari 5 anggota yang dipilih secara heterogen. Siswa diminta untuk mengerjakan soal untuk berkelompok. Soal yang diberikan berupa tugas produk yaitu membuat diagram batang yang dihias semenarik mungkin dan sesuai dengan perintah soal yang telah diberikan. Dalam kegiatan berkelompok terdapat 2 kelompok yang selalu ramai dan kurang kompak dengan kelompoknya karena asyik berkeliling kelas melihat pekerjaan temannya. Pada kegiatan berkelompok, Pak B berkeliling untuk membantu siswa yang mengalami kesulitan dalam memahami lembar kegiatan siswa (LKS). Pak B mengamati dan menilai kegiatan yang dilakukan oleh siswa. Pak B juga menjelaskan soal pada LKS kepada kelompok yang belum memahami.

Setiap kelompok aktif dalam kegiatan membuat diagram batang, namun terdapat salah satu siswa yang kurang aktif dalam kegiatan berkelompok tersebut. Berdasarkan penuturan Pak B, siswa tersebut merupakan siswa yang sempat dikucilkan karena suka mengambil barang milik temannya. Oleh karena itu, siswa lain takut untuk berinteraksi dengan siswa tersebut. Beberapa siswa lain tampak berkeliling untuk meminjam peralatan dan melihat karya dari kelompok lain. Setelah selesai mengerjakan LKS, Pak B meminta semua kelompok untuk menunjukkan hasil karyanya ke depan kelas, dan meminta tanggapan dari kelompok lainnya. Setelah itu Pak B meminta siswa untuk mengerjakan soal evaluasi.

Dalam menganalisis faktor kesulitan belajar siswa pada pelajaran matematika, siswa diberi angket faktor kesulitan belajar. Angket bersifat tertutup dengan 4 dengan pilihan jawaban, selalu; sering; kadang-kadang; dan tidak pernah. Pernyataan dalam angket terdiri dari 15 pernyataan untuk faktor kesulitan belajar intern dan 15 pernyataan untuk faktor kesulitan belajar ekstern. Hasil belajar siswa diperoleh melalui studi dokumentasi yaitu data hasil belajar yang dimiliki oleh guru kelas V. Berdasarkan data hasil belajar, ditemukan 9 siswa memperoleh nilai di bawah, 1 siswa sesuai dengan KKM, dan 14 siswa di atas KKM. Berdasarkan data hasil belajar siswa diambil 3 sampel dengan kategori pengambilan sampel siswa I yang mendapat nilai paling rendah (ETDF), siswa II yang mendapat nilai sedang atau sesuai dengan KKM (MS), dan siswa III yang mendapat nilai paling tinggi (UK).

\section{Faktor Kesulitan Belajar Siswa}

Berdasarkan jawaban dari ketiga sampel dan hasil angket yang telah diberikan kepada siswa kelas V, dapat disimpulkan bahwa terdapat dua faktor yang mempengaruhi kesulitan belajar siswa, meliputi faktor intern dan ekstern. Berdasarkan data yang diperoleh melalui angket, persentase siswa yang mengalami kesulitan belajar lebih dari 50\%. Faktor kesulitan intern dalam kategori 
tinggi sebanyak 16\%, dan faktor kesulitan ekstern dalam kategori tinggi sebanyak 48\%. Secara keseluruhan, rata-rata siswa yang mengalami faktor kesulitan belajar intern dan ekstern di kelas $\mathrm{V}$ SDN Pagersari I dalam kategori tinggi sebanyak 36\%. Hal ini menunjukkan pentingnya mengetahui faktor penyebab kesulitan belajar siswa, sehingga tidak memberi efek negatif terhadap hasil belajar siswa selanjutnya (Alang, 2015).

Siswa yang memiliki faktor kesulitan belajar intern dan ekstern pada saat kegiatan pembelajaran matematika masih dapat mengikuti kegiatan belajar mengajar dengan cukup baik dan termasuk dalam kategori aktif. Hanya terdapat satu siswa yang kurang aktif dalam kegiatan pembelajaran. Hal ini menunjukkan bahwa keaktifan belajar siswa tidak cukup untuk dapat mendeteksi kesulitan belajar siswa. Dibutuhkan seperangkat tes untuk mendiagnosa kesulitan belajar siswa, khususnya dalam matematika (Duskri, dkk., 2014; Nursalam, 2016).

\section{Faktor intern yang mempengaruhi kesulitan belajar siswa pada mata pelajaran matematika}

Faktor intern yang menonjol dalam kesulitan belajar matematika siswa kelas V SDN Pagersari I terkait dengan faktor psikologis dan fisiologis. Faktor psikologis yang dimaksud yaitu minat bakat dan IQ siswa. Minat dan motivasi pada mata pelajaran matematika yang kurang menjadi penyebab utama kesulitan siswa dalam belajar matematika. Hasil ini sejalan dengan hasil penelitian Triyono (2011) yang menyebutkan bahwa minat dan motivasi faktor intern yang mempengaruhi kesulitan belajar matematika siswa. Kurangnya minat dan motivasi pada mata pelajaran matematika dapat menimbulkan rendahnya hasil belajar yang diperoleh.

Berdasarkan data yang diperoleh diketahui faktor intern kesulitan belajar yang mayoritas dialami oleh siswa kelas $\mathrm{V}$ pada mata pelajaran matematika adalah faktor psikologis terkait minat dan motivasi sebesar 62,5\%, kemudian IQ sebesar 58\%. Faktor kesulitan belajar yang paling rendah adalah faktor fisiologi atau kesehatan siswa, yaitu 48\%. Rata-rata faktor kesulitan belajar intern adalah $55,93 \%$.

\section{Faktor ekstern yang mempengaruhi kesulitan belajar siswa pada mata pelajaran matematika}

Faktor ekstern yang mempengarui kesulitan belajar matematika siswa kelas V SDN Pagersari I adalah dari faktor terkait buku bacaan, media massa dan faktor keluarga. Faktor ekstern terkait buku bacaan dialami $72 \%$ siswa. Kurangnya buku bacaan pendukung pembelajaran matematika menyebabkan siswa mengalami kesulitan belajar matematika (Cahyono, 2019). Selain buku bacaan pendukung pembelajaran, adanya buku bacaan lain juga dapat mengganggu fokus belajar siswa. Faktor ekstern berikutnya adalah media massa (HP dan televisi) sebanyak 68\%, dan 62, $2 \%$ dari faktor keluarga.

Rata-rata faktor kesulitan belajar siswa ekstern adalah 59,3\%. Faktor kesulitan belajar ekstern terendah adalah sarana dan prasarana sekolah, yaitu 35\%. Faktor ekstern terkait media massa yaitu seringnya anak lupa untuk belajar karena terlalu asyik bermain HP atau menonton TV. Hal ini 
sesuai dengan Satrianawati (2017) yang mengungkapkan bahwa siswa yang sering menggunakan HP cenderung malas belajar dan menyukai cara instan dalam menyelesaikan masalah. Triasih (2019) mengemukakan bahwa anak yang menonton televisi juga akan menjadi malas belajar dan mengerjakan pekerjaan rumah. Dengan efek negatif yang dihasilkan oleh media ini diharapkan orang tua dapat mengawasi dan membatasi anak dalam berinteraksi dengan media tersebut tidak lebih dari 3 jam setiap harinya (Satrianawati, 2017).

Faktor perhatian orang tua juga menyebabkan siswa kesulitan dalam belajar, hal ini dikarenakan anak mengerjakan sendiri soal yang dirasa sulit di rumah tanpa adanya bantuan dari orang tua. Fenomena terkait faktor ekstern yang menyebabkan siswa kesulitan belajar matematika ini menunjukkan bahwa peran orang tua tidak dapat dipisahkan dari prestasi belajar anak. Rumbewas, dkk. (2018) mengemukakan bahwa peran orang tua dalam pembelajaran anak dapat menjadi faktor pendukung juga di lain pihak dapat menjadi faktor penghambat. Oleh karena itu, perlunya kesadaran orang tua untuk selalu memberikan perhatian dan dukungan dalam proses belajar anak.

\section{Analisis Faktor Kesulitan belajar Ditinjau Dari Hasil Belajar Matematika}

Berdasarkan hasil wawancara dengan guru kelas V dan 3 subjek wawancara, diketahui bahwa kesulitan siswa dalam belajar matematika meliputi, siswa kurang memahami soal khususnya pada pemecahan masalah matematika dan siswa tidak bisa menyelesaikan masalah matematika. Kesulitan ini disebabkan oleh faktor intern dan ekstern. Faktor intern meliputi kurangnya minat, motivasi, IQ dan kesehatan mental siswa, sedangkan faktor ekstern yang dialami siswa adalah adanya buku bacaan lain, lingkungan keluarga dan media massa.

Sampel dipilih dengan kriteria siswa yang memperoleh nilai paling rendah, sesuai dengan KKM, serta yang mendapat nilai paling tinggi. Sampel diketahui memiliki faktor kesulitan belajar intern dan ekstern. Sampel yang mendapat nilai paling rendah memiliki faktor kesulitan belajar dari intern dan ekstern di atas 50\%. Siswa dengan hasil belajar sesuai KKM memiliki faktor kesulitan belajar intern di atas 50\%. Semenatra itu, siswa dengan hasil belajar di atas KKM memiliki faktor kesulitan belajar ekstern di atas $50 \%$.

Sampel pertama (ETDF) mengalami kesulitan belajar yang menonjol dari kedua faktor, intern dan ekstern. Hal ini diperkuat dengan pernyataan guru kelas V yang menyatakan:

“...ETDF merupakan siswa yang paling banyak memiliki masalah dengan keluarganya ...”

Kesulitan belajar yang dialami siswa dengan hasil belajar rendah memerlukan perhatian khusus, baik dari pihak sekolah maupun keluarga. Pendampingan serta pengawasan waktu belajar dari orang tua yang maksimal akan mampu mengatasi kesulitan belajar siswa (Ambaryanti, 2013). Dalam mengatasi kesulitan belajar ini, guru dapat memberikan pembelajaran remedial terhadap 
siswa tersebut (Yeni, 2017). Pemberian pembelajaran remedial juga perlu disesuaikan ddengan karakteristik dan gaya belajar siswa agar diperoleh hasil yang optimal.

Hasil penelitian Darijani, dkk. (2015) mengemukakan faktor kesulitan belajar matematika siswa kelas $\mathrm{V}$ sekolah dasar meliputi minat dan motivasi, faktor lingkungan sosial, dan faktor kurikulum. Hasil penelitian ini menguatkan minat dan motivasi serta faktor lingkungan, khususnya keluarga, sebagai faktor yang perlu mendapat perhatian khusus dalam mengatasi kesulitan belajar matematika siswa. Sebagai salah satu alternatif pemecahan masalah ini, perlunya pengembangan kompetensi guru sekolah dasar dalam mengembangkan metode, media, ataupun alat peraga yang dapat meningkatkan minat dan motivasi siswa pada pembelajaran matematika (Murdiyanto \& Mahatama, 2014).

\section{SIMPULAN DAN SARAN}

\section{Simpulan}

Berdasarkan hasil penelitian dan pembahasan yang telah dijelaskan maka diperoleh kesimpulan sebagai berikut. Rata-rata faktor kesulitan belajar ekstern adalah 59,8\%, sementara rata-rata faktor kesulitan belajar intern sebanyak 56.067\%. Rata-rata faktor kesulitan belajar (intern dan ekstern) yang dialami oleh siswa adalah 58,23\%. Berdasarkan hasil ini faktor kesulitan belajar matematika siswa kelas V SDN Pagersari I berada pada kategori “Tinggi”.

Faktor kesulitan belajar intern yang paling banyak dialami siswa adalah minat dan motivasi, IQ, dan kesehatan mental siswa. Faktor kesulitan belajar ektern yang dialami siswa SDN Pagersari I adalah dari faktor buku bacaan, media massa (HP dan Televisi), lingkungan keluarga dan masyarakat, serta sarana dan prasarana pendukung pembelajaran matematika. Sebanyak 36\% siswa kelas V mengalami kesulitan belajar dalam kategori tinggi. Siswa yang mengalami faktor kesulitan intern saja mendapatkan hasil belajar yang sedang, siswa yang mendapatkan faktor kesulitan ektern saja, rata-rata mendapatkan nilai yang tinggi. Siswa yang mengalami faktor kesulitan intern dan ekstern memiliki hasil belajar yang rendah. Semakin banyak faktor kesulitan belajar yang dialami siswa cenderung dapat menyebabkan siswa mengalami kesulitan belajar.

\section{Saran}

Beberapa saran yang diharapkan akan membantu pihak-pihak yang berkaitan dengan hasil penelitian ini, antara lain, bagi Guru Kelas V sebaiknya pembelajaran dirancang dan dilaksanakan dengan menggunakan media dan alat peraga menarik dan berbeda-beda sehingga siswa dapat menyukai dan tertarik untuk mempelajari mata pelajaran matematika. Sekolah sebaiknya menyediakan berbagai media dan alat peraga matematika karena selama penelitian, banyak siswa yang menganggap matematika mata pelajaran yang sulit dan membosankan. Orang tua sebaiknya senantiasa memberikan perhatian dan pengawasan kepada anaknya saat belajar. Orang tua 
diharapkan dapat membuat suasana senyaman mungkin untuk mendukung anak belajar. Hal ini dikarenakan siswa yang mengalami masalah terutama dalam lingkungan keluarga akan mengalami gangguan kesehatan mental. Kondisi ini akan mengakibatkan siswa malas untuk belajar.

\section{DAFTAR RUJUKAN}

Ahmadi, A. dan Supriyono, W. (2008). Psikologi Belajar. Jakarta: PT Rineka Cipta.

Alang, S. (2015). Urgensi Diagnosis Dalam Mengatasi Kesulitan Belajar. Al-Irsyad Al-Nafs: Jurnal Bimbingan dan Penyuluhan Islam, 2(1).

Ambaryanti, R. (2013). Hubungan Intensitas Pendampingan Belajar Orang Tua dengan Kualitas Hasil Belajar Siswa di Ra Al-Islam Mangunsari 02 Semarang Tahun Pelajaran 2011/2012. Indonesian Journal of Early Childhood Education Studies, 2(2).

Cahyono, H. (2019). Faktor-Faktor Kesulitan Belajar Siswa MIN Janti. Jurnal Dimensi Pendidikan dan Pembelajaran, 7(1), 1-4.

Darjiani, N. N. Y., Meter, I. G., Negara, I. G. A. O., \& Ke, S. P. M. (2015). Analisis kesulitankesulitan belajar matematika siswa kelas V dalam implementasi kurikulum 2013 di SD Piloting se-kabupaten Gianyar tahun pelajaran 2014/2015. MIMBAR PGSD Undiksha, $3(1)$.

Duskri, M., Kumaidi, K., \& Suryanto, S. (2014). Pengembangan Tes Diagnostik Kesulitan Belajar Matematika di SD. Jurnal Penelitian dan Evaluasi Pendidikan, 18(1), 44-56.

Evita, Z., Rahmi, R., \& Efendi, Y. (2015). Analisis Faktor Kesulitan Belajar pada Mata Pelajaran Ilmu Pengetahuan Alam (IPA) Siswa Kelas VII MTs Batamiyah Batam. SIMBIOSA, 4(1).

Jamaris, M. (2009). Kesulitan Belajar: Perspektif, Asesmen, dan Penanggulangannya. Jakarta: Yayasan Penamas Murni.

Judiani, S. (2010). Implementasi Pendidikan Karakter di Sekolah Dasar Melalui Penguatan Pelaksanaan Kurikulum. Jurnal Pendidikan dan Kebudayaan, 16(9), 280-289.

Moleong, L. J. (2016). Metodologi Penelitian Kualitatif. Bandung : Remaja Rosdakarya

Murdiyanto, T., \& Mahatama, Y. (2014). Pengembangan Alat Peraga Matematika Untuk Meningkatkan Minat dan Motivasi Belajar Matematika Siswa Sekolah Dasar. Sarwahita, 11(1), 38-43.

Nofitasari, I., \& Sihombing, Y. (2017). Deskripsi Kesulitan Belajar Peserta Didik dan Faktor Penyebabnya dalam Memahami Materi Listrik Dinamis Kelas X SMA Negeri 2 Bengkayang. Jurnal Penelitian Fisika dan Aplikasinya (JPFA), 7(1), 44-53.

Nursalam, N. (2016). Diagnostik Kesulitan Belajar Matematika: Studi Pada Siswa SD/MI Di Kota Makassar. Lentera Pendidikan: Jurnal Ilmu Tarbiyah dan Keguruan, 19(1), 1-15.

Redja, M. (2010). Filsafat Ilmu Pendidikan. Bandung: PT Remaja Rosdakarya.

Rumbewas, S. S., Laka, B. M., \& Meokbun, N. (2018). Peran Orang Tua Dalam Meningkatkan Motivasi Belajar Peserta Didik di SD Negeri Saribi. EduMatSains: Jurnal Pendidikan, Matematika dan Sains, 2(2), 201-212.

Satrianawati, S. (2017). Dampak Penggunaan Handphone Terhadap Aktivitas Belajar Siswa Sekolah Dasar. Profesi Pendidikan Dasar, 1(1), 54-61.

Sugiyono. (2014). Metode Penelitian Pendidikan (Pendekatan Kuantitatif, Kualitatif dan R\&D). Bandung: Alfabeta

Trisiah, A. (2019). Dampak Tayangan Televisi pada Pola Komunikasi Anak. Jurnal Inovasi, 13(1), $34-45$. 
Triyono, A. (2011). Identifikasi faktor penyebab kesulitan belajar matematika di kelas rendah SD Negeri Karangtengah 1 Kecamatan Sananwetan Kota Blitar. Skripsi tidak diterbitkan, Jurusan Kependidikan Sekolah Dasar \& Prasekolah, Fakultas Ilmu Pendidikan Universitas Negeri Malang.

Waskitoningtyas, R. S. (2016). Analisis Kesulitan Belajar Matematika Siswa Kelas V Sekolah Dasar Kota Balikpapan Pada Materi Satuan Waktu Tahun Ajaran 2015/2016. JIPM (Jurnal Ilmiah Pendidikan Matematika), 5(1), 24-32.

Yeni, E. M. (2017). Kesulitan Belajar Matematika di Sekolah Dasar. Jurnal Pendidikan Dasar (Jupendas), 2(2). 